\title{
National and International Conferences and Events
}

For detailed information please see http://www.phytomedizin.org

\section{Meetings of the German Society of Plant Protection and Plant Health (Deutsche Phytomedizinische Gesellschaft e.V., DPG) \\ 16.03.2015 47. Annual Meeting of the DPG-Working Group Plant Virology. Berlin, Germany. \\ 17.03.2015 43. Annual Meeting of the DPG-Working Group Nematology. Monheim, Germany.}

19.03.2015 Annual Meeting of the DPG-Working Group Mycology. Halle, Germany.

19.03.2015 Annual Meeting of the DPG-Working Group Host-Parasite-Interactions. Halle, Germany.

25.06.2015 Meeting of the DPG-Working group Biometry and Experimental Methods

03.09.2015 Annual Meeting of the DPG-Working Group Phytobacteriology. Karlsruhe, Germany.

17.09.2015 Meeting of the DPG-Working group Phytomedicine in the Tropics and Subtropics. Berlin, Germany.

10.11.2015 20 th Annual Meeting of the DPG-Working Group Vertebrates.

11.11.2015 $18^{\text {th }}$ Annual Meeting of the DPG-Working Group Storage Protection.

18.11.2015 Meeting of the DPG-Working Group Microbial Symbioses, Veitshöchheim, Germany.

07.12.2015 Resistenztagung Fulda

23.02.2016 27th German Conference on Weed Biology and Weed Control Unkrauttagung, Braunschweig, Germany.

Further Meetings and Events

23.03.2015 8th International Integrated Pest Management (IPM) Symposium. Salt Lake City, USA.

24.03.2015 61st Annual Meeting of the Conference on Soilborne Plant Pathogens. University of California-Riverside, USA.

07.04.2015 International Symposium on GA3 Tropical Fruit (Guava, Wax Apple, Pineapple and Sugar Apple). Kaohsiung County, Chinese Taipei.

09.04.2015 Coppice Forests. Past, present and future. International Conference. Brno, Czech Republic.

14.04.2015 Eucarpia Leafy Vegetables Symposium. San Pedro del Pinatar, Spain.

19.04.2015 VI International Symposium on Production and Establishment of Micropropagated Plants. San Remo, Italy.
20.04.2015 III International Symposium on Organic Matter Management and Compost Use in Horticulture. Murcia, Spain.

21.04.2015 II International Workshop on Bacterial Diseases of Stone Fruits and Nuts. Izmir, Turkey.

22.04.2015 2nd Mediterranean Symposium on Medicinal and Aromatic Plants (MESMAP-2). Antalya, Turkey.

28.04.2015 Living Soils Conference, 7th meeting of the IOBC-WPRS Working Group on "Multitrophic Interactions in Soil". Wageningen, The Netherlands.

01.05.2015 III International Conference on Quality Management in Supply Chains of Ornamentals (QMSCO 2015). Shiraz, Iran.

03.05.2015 SETAC (Society of Environmental Toxicology and Chemistry) Europe 25th Annual Meeting. Barcelona, Spain.

04.05.2015 Eucarpia International Symposium on Protein Crops - Plant Proteins for the Future. Pontevedra, Spain.

11.05.2015 Plant Health for Sustainable Agriculture Conference. Ljubljana, Slovenia.

16.05.2015 The X International Symposium on Thysanoptera and Tospoviruses. Brasilia, Brasil.

18.05.2015 V International Symposium on Ecologically Sound Fertilization Strategies for Field Vegetable Production. Beijing, China.

19.05.2015 67th International Symposium on Crop Protection (ISCP). Ghent, Belgium.

21.05.2015 VII International Symposium on Edible Alliaceae. Nigde, Turkey.

24.05.2015 16. Internationale EWAC (European Wheat Aneuploid/Cereals Genetics Co-operative) Konferenz. Lublin, Poland.

26.05.2015 CIOSTA 2015 Conference: Environmently friendly Agriculture and Forestry for Future Generations. Saint-Petersburg, Russia.

31.05.2015 XVIII International Symposium on Horticultural Economics and Management. Alnarp, Sweden.

01.06.2015 Global Challenges of Air Pollution and Climate Change to Forests. Nice, France.

08.06.2015 VIII International Symposium on Irrigation of Horticultural Crops. Lleida, Spain.

08.06.2015 23rd International Conference on Virus and other Graft Transmissible Diseases of Fruit Crops. Moriaka, Japan. 